\title{
Acute occupational phosphine intoxications in the maritime shipping sector: Belgian and French reported cases
}

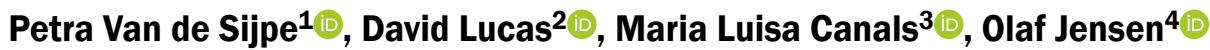 \\ ${ }^{1}$ Belgian Poison Centre, Bruxelles, Belgium \\ ${ }^{2}$ Centre for Professional and Environmental Pathologies, Morvan Teaching Hospital (CHRU), Brest, France \\ ${ }^{3}$ Cadix University, Cadix, Spain \\ ${ }^{4}$ Centre of Maritime Health and Society, Institute of Public Health, University of Southern Denmark, Esbjerg, Denmark
}

\begin{abstract}
Background: During ship transport of organic cargo e.g. soybeans in bulk or textiles in containers, there is a risk of pests damaging the cargo during transport as well as of unwanted global spread of organisms. Consequently, fumigation of the shipped goods is recommended. While aiming to protect the cargo from being damaged by pests during the transport time, fumigation constitutes a risk to the health of seafarers and port workers and even fatal cases are seen. Phosphine gas is increasingly applied for fumigation. Based on former experiences this article aims to describe the risk and to provide recommendations for prevention. Materials and methods: All reports of acute occupational exposures to phosphine in the maritime shipping industry to the Belgian Poison Centre were analysed and compared to reports in a study by ANSES (Agence nationale de sécurité sanitaire de l'alimentation, de l'environnement et du travail), which collected data from the French Poison Centres. Data were registered and analysed between the $1^{\text {st }}$ of January 1999 and the 31 of December 2018.

Results: The reported incidents have so far been rather few but seem to have increased over the last years. Symptoms are gastro-intestinal, neurologic and respiratory and often seem "vague" and non-specific and are often difficult to recognise for first responders. In the cases where the aetiology of the incident is known, there often seems to be a lack of clear information about the risk and options for mitigation in workplaces and among the workers. Twelve publications of case reports were included from the literature review that showed the same patterns as found in the registered incident reports.

Conclusions: There seems to be an increase in incidents of acute poisoning from phosphine worldwide. This increase could be linked to the phasing out of methyl bromide in the Montreal Protocol but may also have other explanations. Strict precautions are needed when using phosphine for fumigation of ship cargoes and containers. Since symptoms are often vague, first-responders need to pay attention to the possible occurrence of acute phosphine intoxication as it may be life threatening. Phosphine intoxication remains a diagnosis nor to underestimate not to miss. Further monitoring and research is needed. Preventive actions are mandatory. It is essential to implement in a strict way the existing legislation of an in-transit fumigation with phosphine. Training of the crew and good communication between the different actors during an in-transit fumigation (ship-owner, captain, fumigator, crew, longshoremen) is the key of a good prevention of accidents.
\end{abstract}

(Int Marit Health 2020; 71, 3: 151-159)

Key words: acute phosphine intoxication, occupational, maritime, incidence reports, shipping 


\section{INTRODUCTION}

The maritime shipping sector has known an exponential growth over the last 20 years.

United Nations Conference on Trade And Development reports that worldwide, in 2017, 753 million twenty-foot equivalent units of containers were handled in ports [1]. World container port throughput grew by 6 per cent between 2016 and 2017. They also report an increase of 7\% for grain transport [2]. The intercontinental liner shipping travel between Europe, America and Eastern and South-Eastern Asia is very high [2]. The International Chamber of Shipping reports that $90 \%$ of the world trade is carried by the international maritime shipping industry which makes maritime shipping the "life blood of the global economy" [3].

To prevent the spreading of unwanted organisms, the Food and Agriculture Organisation recommends the shipped goods to be fumigated [4]. On the one hand with the aim to protect the cargo from being damaged by pests during the transport time, and on the other hand - and even more important - with the aim to prevent the spread of pests all over the world and thus to protect human health. Marine fumigation or in-transit fumigation is a process of fumigation where fumigant is applied to the ship's hold at the port of loading the cargo. The technical process of marine fumigation has been described in an earlier article [5]. During the voyage, the ship's Master is responsible for maintaining safe conditions in all occupied area.

An important element is that at the discharge port, before unloading the cargo, there is a process of phosphine degassing.

According to International Maritime Organisation (IMO) Recommendations on the safe Use of Pesticides in Ships, the only fumigant which can be used for this is type of fumigation is phosphine [6].

There is a strict legislative framework for marine in transit fumigation with phosphine [7]: At sea the Recommendations on the Safe Use of Pesticides in ships has to be implemented, but also the IMO International Dangerous Goods code, the International Convention for Safe Containers, and the code of Practice for Packing of Cargo Transport Units (CTU code) have to be followed. While European Union regulations and various national rules are dominant in port or at the end-user, the IMO, Safety Of Life At Sea, United Nations and International Convention for the Prevention of Pollution from Ships MARPOL regulations and recommendations, are limited to circumstances at sea.

Phosphine, when used as a fumigant, is applied in two physical forms: as a gas from pressurised cylinders or as a metallic phosphide, such as aluminium phosphide, magnesium phosphide, calcium phosphide, or zinc phosphide which react with ambient moisture to release phosphine gas [6].
In harbours the exposure to phosphine mostly occurs when dock workers unload the cargo from a fumigated container or bulk carrier or when customs officers inspect goods. Different very interesting studies have been done with measurements of gases in imported containers in European harbours [8-15] and European Union-Occupational and Safety Health (EU-OHSA) published in 2018 a bibliographic and analytic report pointing out quite some problems [16].

EU-OHSA concludes in the report that the occupational exposure limit (OEL) of phosphine is exceeded in $0.4 \%$ to $3.5 \%$ of the analysed containers. They realised that most containers are never labelled, that there is often absence of standardised protocols (measurement technology/strategy, degasification/ventilation and personal protective equipment and that incidents affecting the worker's health are underreported.

Those studies concern all fumigants, but the scope of this article is to study exclusively acute exposure to phosphine seen taken into account its frequent use for in-transit fumigation. In France, measurements have been done in harbours exclusively for phosphine and the OEL of phosphine was as well exceeded which indicates that there is a risk in our European harbours [5].

The aim of this study is to explore if accidents with acute occupational exposure to phosphine happen in the Belgian and French shipping industry.

The subsequent research questions are:

- If those incidents happen, what is the frequency?

- Is there an increasing trend in the frequency of those incidents?

- What is the extent, the nature and the severity of those incidents?

- Is it possible to explore the background of those incidents in order to explore a better prevention?

\section{MATERIALS AND METHODS}

Observational, routinely collected health data were used and reported according to the RECORD Statement [17].

This is a cross-sectional study. In this study data only included the cases officially reported to the Belgian Poison Centre. Cases are anonymous. For each case, we collected data listed below.

\section{PARTICIPANTS}

Only occupational exposures and exposures in the maritime shipping industry have been included. Data were registered between the $1^{\text {st }}$ of January 2000 and the 31 of December 2018. An incident is defined as an accidental occupational exposure. Whether the narrative tells when it is linked to the maritime industry, whether the emergency services from the port areas (Antwerp, Zeebrugge) which contacted the Belgian Poison Centre have been retraced. A victim or case has been defined as the object of an ac- 
cidental exposure. Victims with or without symptoms were included as cases.

\section{VARIABLES}

In the Belgian Poison Centre every call is registered, and a file is made. When we have several calls for the same incident, we connect the files.

\section{DIAGNOSTIC CRITERIA}

The clinical severity of the incident has been evaluated by the "Poisoning Severity Score' (PSS) [18]. The global clinical severity of an incident corresponds to the highest severe clinical symptom mentioned in an incident. The PSS has been reviewed with a member of the board of the European Association of Poisons Centres and Clinical Toxicologists.

- the PSS is 0 if there are no symptoms;

- the PSS is 1 or minor if there are mild, transient and spontaneously resolving symptoms;

- the PSS is 2 or moderate if there are pronounced or prolonged symptoms;

- the PSS is 3 or severe if there are severe or life-threatening symptoms;

- the PSS is 4 if symptoms are fatal.

Those data will be compared to a study of the Agence Nationale de Sécurité Sanitaire de l'alimentation, de l'environnement et du travail, France (ANSES) [19, 20]. ANSES did as well as a cross-sectional study, including the cases of acute occupational exposure to phosphine which have been reported to the French Poison Centres. They reported all occupational exposures, thus not only those in the maritime shipping industry. The time frame of their study was 1999-2017. They only included symptomatic exposures.

\section{LITERATURE REVIEW}

For discussion, we also performed a literature review. It was performed in PubMed between September 2017 and April 2018. The search terms included a combination of phosphine and derivatives of phosphine, seafarers, different types of ships and fumigation. It was constructed as a block-analysis which consisted of three blocks-columns-divided by the Boolean operator "AND". The words in the same block were divided by the Boolean operator "OR" with "Phosphine", "Ships", "Boats" and "Fumigation(s)" as MESH-terms.

\section{STATISTICAL METHODOLOGY}

Chi-square trend analysis in SPSS was used to evaluate the trend of incidences over the years.

\section{RESULTS}

In total, we retrieved 34 calls for occupational exposure to phosphine covering 24 incidents with 26 victims. Of the overall occupational exposure to phosphine, 16 of the
24 (66.6\%) incidents happened in ports. Those 16 incidents occurring in the maritime shipping industry covered 18 victims which is $69.2 \%$ of the total number of victims having been exposed to phosphine or metal phosphides. All cases are listed in Table 1. The trendanalysis is represented in Figure 1.

\section{DISTRIBUTION OF SYMPTOMS}

Seven victims presented nausea and 4 vomiting, which makes gastro-intestinal symptoms being the majority of the symptoms (66.6\%). Six (33.3\%) victims presented respiratory symptoms and 7 (38.8\%) victims presented neurological symptoms.

Gastro-intestinal symptoms included nausea, vomiting and abdominal pain. Respiratory symptoms included respiratory tract irritation, cough and bronchospasm. Neurological symptoms included mostly headache. Ten victims presented other symptoms such as mucosa irritation, dry mouth, myalgia, sleepiness, fever. One patient presented a kind of allergic reaction with Quincke oedema, but that patient was exposed to phosphine in a hold with rice containing mycotoxins which could have contributed to the symptoms.

\section{DISCUSSION}

Phosphine is a colourless, flammable gas with a smell of garlic or rotten fish. The threshold of olfactory detection in humans varies according to individuals but seems to appear above $0.3 \mathrm{ppm}[21]$.

The main route of systemic absorption is through the lungs. Phosphides can also be absorbed through damaged skin [21]. For workers, the major risk is mainly during acute exposure. Phosphine interferes with the electron transport chain in mitochondria and mainly in myocardial and hepatic cells. For myocardial cells, an alteration of the transmembrane potentials causing arrhythmia and hypotension was described. Cardiac arrest, vascular collapse and pulmonary oedema may occur [22]. Pulmonary involvement with oedema and chemical pneumonia would result from the cytotoxicity of the gas on the lung cells. In lethal cases, hepatic centrilobular necrosis was diagnosed [22]. The majority of deaths occur within 12 to 24 hours of exposure and are related to cardiac effects. Cardiovascular toxicity is reversible. The risk of death arises with exposure greater than $400 \mathrm{ppm}$ of phosphine and after 30 minutes. Health problems could also occur with a concentration lower than 50 ppm [23]. Phosphine depresses the central nervous system and also the peripheral nervous system. The clinical signs described during acute intoxication are directly due to gas toxicity. The first symptoms are pulmonary and gastrointestinal. With exposure with high concentration neurological and muscular signs 
Table 1. List of cases from the Belgian Poison Centre

\begin{tabular}{|c|c|c|c|c|c|c|}
\hline \multicolumn{7}{|c|}{ Incidents reported to the Belgian Poison Centre } \\
\hline $\begin{array}{l}\text { No. incident } \\
\text { No. case }\end{array}$ & $\begin{array}{l}\text { Date } \\
\text { Place }\end{array}$ & $\begin{array}{l}\text { Number } \\
\text { of victims }\end{array}$ & $\begin{array}{l}\text { Route of } \\
\text { exposure } \\
\text { Symptoms }\end{array}$ & PSS & $\mathbf{I}$ & Narrative \\
\hline $\begin{array}{l}1 \\
\text { Case no. } 1\end{array}$ & $\begin{array}{l}2000 \\
\text { Port } \\
\text { of Antwerp }\end{array}$ & 1 & $\begin{array}{l}\text { Inhalation } \\
\text { Vomiting } \\
\text { Agitation }\end{array}$ & PSS 1 & $\mathrm{I}_{2}$ & $\begin{array}{l}\text { A dock worker who was unloading a container ship in the port of } \\
\text { Antwerp when he was standing in the docks, some meters from } \\
\text { a container but he has inhaled phosphine gas. A priori it seemed } \\
\text { to be a very short and limited exposure but despite he got ill. He } \\
\text { presented with vomiting and was very agitated. He has been admit- } \\
\text { ted to the emergency department of an Antwerp hospital and was } \\
\text { hospitalised for symptomatic treatment, normobaric oxygen and } \\
\text { observation. The BPC was contacted by the emergency physician. }\end{array}$ \\
\hline $\begin{array}{l}2 \\
\text { Case no. } 2\end{array}$ & $\begin{array}{l}2007 \\
\text { Port of } \\
\text { Zeebrugge? }\end{array}$ & 1 & $\begin{array}{l}\text { Inhalation } \\
\text { cutaneous } \\
\text { No symptoms }\end{array}$ & PSS 0 & $\mathrm{I}_{\mathrm{i}}$ & $\begin{array}{l}\text { In a non-specified port (Zeebrugge?), during the unloading of } \\
\text { a container from India, a dock worker has been covered with alu- } \\
\text { minium phosphide powder. There was no smell in the container. } \\
\text { He presented no symptoms. He contacted the BPC } 10 \text { min after } \\
\text { the exposure because he was very concerned and it was advised } \\
\text { to do a good decontamination (removing clothes, shower) and in } \\
\text { case of symptoms to present himself at the emergency depart- } \\
\text { ment of a hospital. }\end{array}$ \\
\hline $\begin{array}{l}3 \\
\text { Case no. } 3\end{array}$ & $\begin{array}{l}2008 \\
\text { Port of } \\
\text { Antwerp }\end{array}$ & 1 & $\begin{array}{l}\text { Inhalation } \\
\text { cutaneous } \\
\text { Ocular } \\
\text { Bronchospasm } \\
\text { Ocular irritation } \\
\text { Cutaneous } \\
\text { irritation } \\
\text { erythema } \\
\text { Angioneurotic } \\
\text { oedema } \\
\text { (Quincke) }\end{array}$ & PSS 2 & $\mathrm{I}_{1}$ & $\begin{array}{l}\text { In the port of Antwerp, a dock worker was unloading a container } \\
\text { with rice, contaminated with mycotoxins and whilst unloading he } \\
\text { got a bag on his head and powder of aluminium phosphide on his } \\
\text { skin which he also inhaled. Immediately, he presented with bron- } \\
\text { chospasm and angioneurotic oedema. His eyes were irritated and } \\
\text { on his skin he got local irritation. The symptoms could also be lin- } \\
\text { ked to the mycotoxins. It is unknown if the worker was asthmatic. } \\
\text { The BPC was contacted by the occupational doctor of Medimar but } \\
\text { it has been advised to hospitalise the patient via the emergency } \\
\text { department for symptomatic treatment and medical observation. }\end{array}$ \\
\hline $\begin{array}{l}4 \\
\text { Case no. } 4\end{array}$ & $\begin{array}{l}2010 \\
\text { Port of } \\
\text { Zeebrugge }\end{array}$ & 1 & $\begin{array}{l}\text { Inhalation } \\
\text { No symptoms }\end{array}$ & PSS 0 & $\mathrm{I}_{\mathrm{i}}$ & $\begin{array}{l}\text { In the port of Zeebrugge, a customs officer was very concerned } \\
\text { since the day before, he had opened a container with a warning } \\
\text { label for hydrogen phosphide/phosphine. He had no complaints } \\
\text { but was very concerned about his health and so anxious that he } \\
\text { presented the next to the emergency department of the hospital } \\
\text { of Brugge. The BPC was contacted by the emergency physician. }\end{array}$ \\
\hline $\begin{array}{l}5 \\
\text { Case no. } 5\end{array}$ & $\begin{array}{l}2010 \\
\text { Port of } \\
\text { Antwerp }\end{array}$ & 1 & $\begin{array}{l}\text { Inhalation } \\
\text { Nausea } \\
\text { Fever }\end{array}$ & PSS 1 & $\mathrm{I}_{1}$ & $\begin{array}{l}\text { On Christmas day a seafarer staying in the port of Antwerp } \\
\text { presented himself with fever (hyperthermia) and nausea at the } \\
\text { emergency department. Apparently his colleague died (no docu- } \\
\text { mentation) some days before, after an exposure to phosphine } \\
\text { gas. He had been exposed too, but it was not really clear when. } \\
\text { The seafarer has been hospitalised. The BPC was contacted by } \\
\text { the emergency physician. }\end{array}$ \\
\hline $\begin{array}{l}6 \\
\text { Case no. } 6\end{array}$ & $\begin{array}{l}2011 \\
\text { Port of } \\
\text { Antwerp }\end{array}$ & 1 & $\begin{array}{l}\text { Inhalation } \\
\text { No symptoms }\end{array}$ & PSS 0 & $\mathrm{I}_{\mathrm{i}}$ & $\begin{array}{l}\text { In the port of Antwerp a dock worker was very briefly exposed to } \\
\text { phosphine gas whilst unloading a container ship. He presented no } \\
\text { symptoms. The patient has been hospitalised in the emergency } \\
\text { department in an Antwerp hospital and the BPC was contacted by } \\
\text { the emergency physician. He has been hospitalised for medical } \\
\text { observation. }\end{array}$ \\
\hline $\begin{array}{l}7 \\
\text { Case no. } 7\end{array}$ & $\begin{array}{l}2012 \\
\text { Port of } \\
\text { Antwerp }\end{array}$ & 1 & $\begin{array}{l}\text { Inhalation } \\
\text { No symptoms }\end{array}$ & PSS 0 & $\mathrm{I}_{\mathrm{i}}$ & $\begin{array}{l}\text { In the port of Antwerp, a dock worker unloading grain from a ship } \\
\text { came into contact with phosphine gas during } 30 \text { min. He presen- } \\
\text { ted no symptoms. He has been hospitalised in the emergency } \\
\text { department of an Antwerp hospital for medical observation. The } \\
\text { BPC was contacted by the emergency physician }\end{array}$ \\
\hline $\begin{array}{l}8 \\
\text { Case no. } 8\end{array}$ & $\begin{array}{l}2013 \\
\text { Port of } \\
\text { Antwerp }\end{array}$ & 1 & $\begin{array}{l}\text { Inhalation } \\
\text { Throat pain }\end{array}$ & PSS 1 & $I_{1}$ & $\begin{array}{l}\text { A dock worker in the port of Antwerp contacts the BPC because } \\
4 \text { days earlier he has been exposed to phosphine. Since than } \\
\text { he has throat irritation/throat pain but at the same time his kids } \\
\text { have a white angina. It has been advised to consult a general } \\
\text { practitioner to make a differential diagnosis. }\end{array}$ \\
\hline
\end{tabular}


Table 1 cont. List of cases from the Belgian Poison Centre

\begin{tabular}{|c|c|c|c|c|c|c|}
\hline \multicolumn{7}{|c|}{ Incidents reported to the Belgian Poison Centre } \\
\hline $\begin{array}{l}\text { No. incident } \\
\text { No. case }\end{array}$ & $\begin{array}{l}\text { Date } \\
\text { Place }\end{array}$ & $\begin{array}{l}\text { Number } \\
\text { of victims }\end{array}$ & $\begin{array}{l}\text { Route of } \\
\text { exposure } \\
\text { Symptoms }\end{array}$ & PSS & 1 & Narrative \\
\hline $\begin{array}{l}9 \\
\text { Case no. } 9\end{array}$ & $\begin{array}{l}2014 \\
\text { Port of } \\
\text { Antwerp }\end{array}$ & 1 & $\begin{array}{l}\text { Inhalation } \\
\text { Nausea } \\
\text { Headache } \\
\text { Vertigo } \\
\text { Myalgia }\end{array}$ & PSS 1 & $\mathrm{I}_{4}$ & $\begin{array}{l}\text { A dock worker in the port of Antwerp has been exposed during } \\
2 \text { min to phosphine gas during the unloading of a cargo ship. He } \\
\text { has been admitted to the emergency department of an Antwerp } \\
\text { hospital since he presented nausea, headache, vertigo and myal- } \\
\text { gia. He has been hospitalised in the emergency department for } \\
\text { symptomatic treatment and medical observation. The BPC has } \\
\text { been contacted by the emergency physician. }\end{array}$ \\
\hline $\begin{array}{l}10 \\
\text { Case no. } 10\end{array}$ & $\begin{array}{l}2015 \\
\text { Port of } \\
\text { Antwerp }\end{array}$ & 1 & $\begin{array}{l}\text { Inhalation } \\
\text { Dry mouth } \\
\text { Pasty mouth } \\
\text { Nausea } \\
\text { Abdominal pain }\end{array}$ & PSS 2 & $I_{1}$ & $\begin{array}{l}\text { A seafarer presented himself to the emergency department of an } \\
\text { Antwerp hospital. Eight days before he has been exposed to pho- } \\
\text { sphine and he still has symptoms: dry mouth, pasty mouth, nau- } \\
\text { sea, abdominal pain. The ship also carried arsine but it seemed } \\
\text { clear the exposure had clearly been to phosphine and not at all } \\
\text { to arsine. He has been hospitalised for a paraclinical and clinical } \\
\text { assessment. The BPC has been contacted by the emergency phy- } \\
\text { sician. }\end{array}$ \\
\hline $\begin{array}{l}11 \\
\text { Case no. } 11\end{array}$ & $\begin{array}{l}2015 \\
\text { Port of } \\
\text { Antwerp }\end{array}$ & 1 & $\begin{array}{l}\text { Inhalation } \\
\text { Nausea } \\
\text { Sleepiness }\end{array}$ & PSS 1 & $\mathrm{I}_{4}$ & $\begin{array}{l}\text { A dock worker was involved in an incident in the port of Antwerp } \\
\text { where a barrel of phosphine was leaking. He has been exposed to } \\
\text { phosphine gas } 2 \text { ppm during } 5 \text { min. He presented nausea and sle- } \\
\text { epiness. He has been hospitalised in the emergency department } \\
\text { for symptomatic treatment and medical observation. The BPC has } \\
\text { been contacted by the emergency physician. }\end{array}$ \\
\hline $\begin{array}{l}12 \\
\text { Case no. } 12\end{array}$ & $\begin{array}{l}2016 \\
\text { Port of } \\
\text { Antwerp }\end{array}$ & 1 & $\begin{array}{l}\text { Inhalation } \\
\text { No symptoms }\end{array}$ & PSS 0 & $I_{i}$ & $\begin{array}{l}\text { A worker in the port of Antwerp consulted the occupational nurse } \\
\text { because he was very concerned. The day before he had been } \\
\text { unloading a ship where the measurements of phosphine seemed } \\
\text { to be positive. He didn't have any symptoms but felt very anxious } \\
\text { about the situation. The occupational nurse contacted the BPC } \\
\text { and it has been advised that the worker got a medical assess- } \\
\text { ment in the emergency department. }\end{array}$ \\
\hline $\begin{array}{l}13 \\
\text { Case no. } 13\end{array}$ & $\begin{array}{l}2017 \\
\text { Goes, } \\
\text { Zeeland }\end{array}$ & 1 & $\begin{array}{l}\text { Inhalation } \\
\text { Dyspnoea } \\
\text { Malaise } \\
\text { Pallor } \\
\text { Paresis } \\
\text { Asthenia }\end{array}$ & PSS 2 & $\mathrm{I}_{3}$ & $\begin{array}{l}\text { A dock worker had been exposed to phosphine } 4 \text { days ago whilst } \\
\text { opening a container in Zeeland Seaport. He complained about } \\
\text { dyspnoea and malaise and he got hospitalised in the emergency } \\
\text { department of the hospital in Goes and afterwards he became } \\
\text { symptom free. Now he presents again in the emergency depart- } \\
\text { ment of an Antwerp complaining of dyspnoea, pallor, paresis and } \\
\text { fatigue. The BPC has been contacted by the emergency physician. } \\
\text { He stayed hospitalised for a medical assessment. }\end{array}$ \\
\hline $\begin{array}{l}14 \\
\text { Case no. } 14\end{array}$ & $\begin{array}{l}2017 \\
\text { Port of } \\
\text { Antwerp }\end{array}$ & 1 & $\begin{array}{l}\text { Inhalation } \\
\text { Respiratory } \\
\text { tract irritation }\end{array}$ & PSS 1 & $\mathrm{I}_{4}$ & $\begin{array}{l}\text { A dock worker in the port of Antwerp was exposed to phosphine } \\
\text { whilst opening a container. The measurements showed pho- } \\
\text { sphine 1.14-0.7 ppm. There was a correct ventilation of the } \\
\text { container. Since the patient presented a respiratory tract irritation } \\
\text { he has been hospitalised in the emergency department of an } \\
\text { Antwerp hospital. The BPC has been contacted by the emergency } \\
\text { physician. }\end{array}$ \\
\hline $\begin{array}{l}15 \\
\text { Case no. } 15 \\
\text { Case no. } 16 \\
\text { Case no. } 17\end{array}$ & $\begin{array}{l}2018 \\
\text { Port of } \\
\text { Antwerp }\end{array}$ & 3 & $\begin{array}{l}\text { Inhalation } \\
\text { Nausea } \\
\text { Vomiting } \\
\text { Cough } \\
\text { Headache } \\
\text { Vertigo }\end{array}$ & PSS 1 & $\mathrm{I}_{4}$ & $\begin{array}{l}\text { In the port Antwerp } 3 \text { dock workers have been exposed to phos- } \\
\text { phine whilst opening a container without knowing about it being } \\
\text { fumigated with phosphine. The exposure time was maximum } \\
5 \text { min. The measurement after the exposition was } 0 \text { ppm. Altho- } \\
\text { ugh they immediately presented nausea, vomiting, cough, heada- } \\
\text { che and vertigo. The have been hospitalised in the emergency } \\
\text { department of an Antwerp hospital for symptomatic treatment } \\
\text { and medical observation. The BPC has been contacted by the } \\
\text { emergency physician. }\end{array}$ \\
\hline $\begin{array}{l}16 \\
\text { Case no. } 18\end{array}$ & $\begin{array}{l}2018 \\
\text { Port of } \\
\text { Antwerp }\end{array}$ & 1 & $\begin{array}{l}\text { Inhalation } \\
\text { Vertigo }\end{array}$ & PSS 1 & $\mathrm{I}_{2}$ & $\begin{array}{l}\text { A dock worker in the port of Antwerp has been exposed to pho- } \\
\text { sphine and presented vertigo. He had consulted a general prac- } \\
\text { titioner who contacted the BPC for advice. Since it was a doctor } \\
\text { on call a follow-up was not possible. }\end{array}$ \\
\hline
\end{tabular}


Number of cases in Belgium

- - Linear trendanalysis (number of cases in Belgium)

1

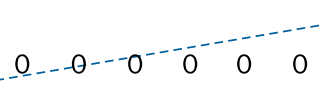

2000200120022003200420052006200720082009201020112002201320142015201620172018

Figure 1. Number of cases in the Belgian Poison Centre

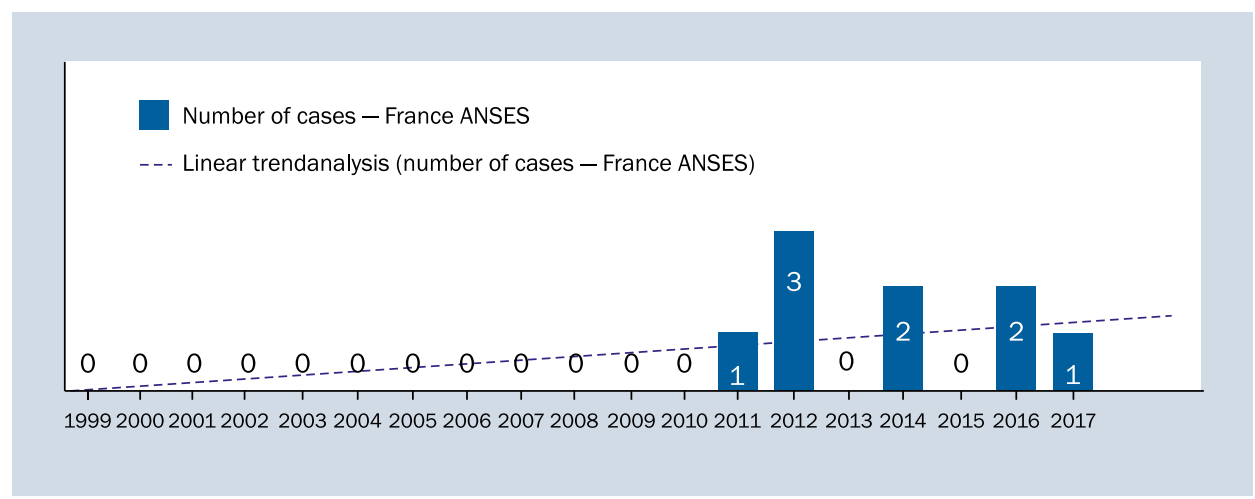

Figure 2. Number of cases in France ANSES (Agence nationale de sécurité sanitaire de l'alimentation, de l'environnement et du travail)

appear [24]. Hepatic disorder usually appear only 48 to 72 hours later with elevated blood transaminases and bilirubin. Haematuria, proteinuria and renal failure could also occur. Signs of respiratory and metabolic acidosis may be revealed in blood gases. Similarly, increased levels of magnesaemia and kalaemia due to massive myocardial cytolysis have been described [22]. The long-term follow-up of intoxicated patients did not show the persistence of these disorders. But, respiratory diseases such as reactive airways dysfunction syndrome could occur after subacute exposure at moderate dose [24]. Anaemia, gastrointestinal, ophthalmological, motor and aphasia disorder have been described after chronic exposure to very low dose. These disorders were especially noted in children [22]. Phosphine is not classified as carcinogenic or reprotoxic by the International Agency for Research on Cancer and the European Protection Agency [25].

In the retrospective study published by the ANSES, 9 incidents and 12 symptomatic victims were retrieved (Fig. 2) [19]. Of the 12 victims, 1 was exposed as a lorry driver and 5 victims were exposed in land whilst opening/working in containers. Like for Belgian Poison Centre there seems to be an increase in cases over the last years in Belgium: comparing the period 2000-2009 (0.002\% of all calls) versus the period 2010-2018 (0.01\%) and in France:
1 case in 2011, 3 cases in 2012, 4 cases in 2014, 2 cases in 2016 and 2 cases in 2017 . This could be linked to the phasing out of methyl bromide in the Montreal Protocol or better knowledge and information on this risk in workers' population. Exposure at work in harbours and in logistic platform was the most frequently described in the two studies. Port workers, seafarers and logistic workers during unloading/loading containers and bulk carriers have higher risk levels of acute exposure to phosphine. This problem of exposure along the transport chain has been reported by different authors [26, 27].

Not surprisingly with high ratio of male in these occupations, in the French and Belgian studies all cases were male. The findings of the French study, even if not exclusively maritime, are very similar to the above described cases from the Belgian Poison Centre. The basic difference is that in the Belgian series of cases are included asymptomatic victims whilst in the French study only symptomatic victims were included.

All cases were exposed to phosphine mostly by inhalation of phosphine gas (respectively 58\% and $89 \%$ in France and Belgium). Most symptoms were irritative (pulmonary and ocular first). Non-specific symptoms were also described in both studies. Like we discussed in a study on 125 French dockers, neurologic symptoms were frequently 
noticed by workers but they are unspecific of exposure to fumigants (dizziness, headaches, sleep disorders) and link to occupational exposure is difficult to prove. Some questionnaires like the Fumex questionnaire developed by the European Society of Occupational and Environmental Medicine and another one by the French Society of Maritime Medicine [28]. We hope that they could be helpful to clinicians. In Belgian cases, more gastrointestinal symptoms were described. This may be explained by higher levels of exposure and more frequently pulmonary exposure in maritime transport.

Neither in the French nor in the Belgian study, any severe symptoms occurred. In the French study 9 of the 12 cases had a PSS 1 and 3 had a PSS 2 . Indeed, the Dutch Poison Centre did a study between February 2011 and January 2013 about the registration of occupational exposure to gases whilst opening sea containers [29]. They registered the calls for information concerning occupational exposure to gases from sea containers. In that period, they were consulted for 14 incidents with 33 victims. In 8 incidents which concerned 24 workers, they could do a follow-up. Three incidents concerned an exposure exclusively to phosphine. The findings in the Dutch study were that all cases of exposures to gases coming from containers had minor symptoms. This corresponds to the findings of Preisser et al. [30, 31] and Verschoor et al. [32]. In all cases of acute exposure included, a medical consultation was made and hospitalisation respectively for 9/12 cases in France and 16/18 in Belgium. There are two explanations for that: the risk of delayed symptoms was known by workers or supervisors and they were addressed to emergency services systematically or more workers were anxious about this occupational exposure and wanted explanations on medical assessment.

Like described in the study by Pedersen et al. [28], workers and supervisors have a limited knowledge about the type of chemicals in containers' atmosphere and their health impact, the second hypothesis seems more realistic.

In the Dutch study, workers declared being anxious about the impact of the acute exposure to fumigants. That anxiety often seems to be caused by a lack of information concerning the risk they have been exposed.

In line with the findings of Preisser et al. [30, 31] and Verschoor et al. [32] the Belgian Poison Centre has as well been contacted concerning longer lasting symptoms. Considering this fact and the findings of the above-mentioned publications, the impact of longer lasting symptoms after an acute exposure to phosphine should not been underestimated. As mentioned earlier in this paper, the EU-OHSA report 2018 points out some problems on the work floor [16]. The report is about all fumigants but gives a line for the situation with phosphine, since phosphine is mainly used for in-transit fumigation. EU-OHSA states that often exposure to fumigants is higher than the OELs, that containers are rarely labelled, that there are few protocols for controlling containers and that reporting of accidents is often not done.

Meanwhile, it is very important that harbours and workplaces implement the recommendations EU-OSHA has given into their report, such as a good risk assessment before opening containers or unloading cargo ships, standardised off-gassing procedures, reinforcement of the legislation concerning labelling of containers and good information towards the workers concerning the possible risks [16].

\section{LIMITATIONS OF THE STUDY}

Our study also has some limitations. Observational routinely collected health data from the Belgian Poison Centre were used and reported according to the RECORD Statement. Those data are not always complete due to substantial reporting deficits depending on the type of records (e.g. used codes and terms and their uniformity) [17]. Only occupational exposures and exposures in the maritime shipping industry have been included. However, it has not been possible to know all details of the exposure, products or to know the outcome of an exposure. Only in some recent cases a follow-up has been done.

In the Belgian registration there are probably quite some cases where phosphine has been released by aluminium phosphide due to the opening of the containers under given meteorological conditions and where phosphine has been mentioned as the toxin but probably coming from aluminium phosphide tablets or sachets [5, 16]. Conclusions are drawn based on the analysis of the pattern and the incidence of the accidents exploring the accidental aetiology, clinical presentation and medical care. Since the poison centres are not always contacted for those incidents, it is an underestimation of the reality. We have also been limited in the data collection. It was also difficult to have relevant information from port instances and hospitals around the ports.

Seen the above-mentioned limitations, the results of the study from the Belgian Poison Centre should be interpreted carefully. Because of non-specific symptoms, lack of workers' and medical doctors' experience of this occupational exposure, most of the incidents are probably never reported.

\section{CONCLUSIONS}

For occupational exposure to phosphine, the findings of the Belgian Poison Centre and the French Poison Centres are showing a tendency of increased numbers of incidents. In Belgium, all victims were male dockers. Most of the symptoms are non-specific. To facilitate safe handling of 
fumigated containers at sea and in port/on land, joint effort from both organisations is needed. Strict precautions are needed when using phosphine in fumigation processes on ships. Different actors in the fumigation process should work together in a transparent way and should be well informed. From ship-owner to crew, captain, harbour instances, dockers and primary health care givers.

The lack of knowledge of stakeholders, workers and physicians needs an answer. We are convinced that, information by means of scientific literature but also by social media or the International Maritime Health Association has to be done. For measures of prevention, like writing in the EU-OSHA report, local or national or international guidelines for safely handling containers and stuffs in maritime industry have to be developed. A European study including most poison centres' databases should be relevant to increase the knowledge on this occupational intoxication.

\section{REFERENCES}

1. Ec.europa.eu. Data - Eurostat maritime transport. https://ec.europa.eu/eurostat/web/transport/data (Accessed 2 December 2019).

2. The United Nations Conference on Trade and DevelopmentUnctad. org. UNCTAD | Statistics. https://unctad.org/en/Pages/Statistics. aspx (Accessed 2 December 2019).

3. International Chamber of Shipping ICS. Shipping Facts. http:// www.ics-shipping.org/shipping-facts/shipping-facts (Accessed 2 December 2019).

4. Food and Agriculture Organization. Manual of fumigation for insect control-Space fumigation at atmospheric pressure. http://www.fao.org/3/ x5042e/x5042EOL.HTM\#Fumigation\%20of\%20bagged\%20goods\%20 in \%20ships\%20and\%20barges (Accessed 2 December 2019).

5. Lucas D, Mauguen G, Lesné $P$, et al. Exposure to phosphine in maritime transport: a real and important occupational risk: a report of three cases. Int Marit Health. 2018; 69(3): 181-183, doi: 10.5603/ imh.2018.0029.

6. International Maritime Organisation IMO. Recommendations on the Safe use of Pesticides in Ships applicable to the fumigation of cargo transport units. http://www.imo.org/blast/blastDataHelper.asp?data_id=22227\&filename=1265.pdf (Accessed 2 December 2019).

7. Low A, Hüsing UP, Preisser A, et al. Regulations and control of in-transit fumigated containers as well as of fumigated cargo ships. Int Marit Health. 2003; 54(1-4): 77-85, indexed in Pubmed: 14974780.

8. Knol-de Vos T. Measuring the amount of gas in import containers - Report 609021025/2003 Bilthoven. Dutch National Institute for Public Health and the Environment. 2002. https://www.rivm.nl/bibliotheek/rapporten/609021024.pdf (Accessed 2 December 2019).

9. Baur X, Poschadel B, Budnik LT. High frequency of fumigants and other toxic gases in imported freight containers - an underestimated occupational and community health risk. Occup Environ Med. 2010; 67(3): 207-212, doi: 10.1136/oem.2008.043893, indexed in Pubmed: 19858536.

10. Spijkerboer $\mathrm{H}$, Vries Ide, Meulenbelt J. Use of fumigants in sea containers can lead to serious human poisonings. Toxicol Lett. 2008; 180: S139-S140, doi: 10.1016/j.toxlet.2008.06.784.

11. Scholtens EJ, De Vr, Meulenbelt J. International transport of fumigated containers, a risk for dock workers. Clin Toxicol. 2009; 47/5(494): 1556-3650.

12. Preisser AM, Heblich F, Budnik LT, et al. Health disorders due to fumigants: Occupational health aspects and long-term findings.
Zentralblatt für Arbeitsmedizin, Arbeitsschutz und Ergonomie. 2009; 59: 180-184.

13. Baur X, Budnik LT, Preisser AM. [Health risks of residual fumigants in international transport containers]. Dtsch Med Wochenschr. 2010; 135(11): 516-521, doi: 10.1055/s-0030-1249198, indexed in Pubmed: 20221968.

14. Baur X, Poschadel B, Budnik LT. High frequency of fumigants and other toxic gases in imported freight containers-an underestimated occupational and community health risk. Occup Environ Med. 2010; 67(3): 207-212, doi: 10.1136/oem.2008.043893, indexed in Pubmed: 19858536.

15. Svedberg U, Johanson G. Work inside ocean freight containers-personal exposure to off-gassing chemicals. Ann Occup Hyg. 2013; 57(9): 1128-1137, doi: 10.1093/annhyg/met033, indexed in Pubmed: 23825354.

16. European Union- Occupational and Safety Health Agency. Handling fumigated containers in ports - health risks and prevention practices - Safety and health at work - EU-OSHA. https://osha.europa. eu/en/tools-and-publications/publications/health-risks-and-prevention- practices-during-handling-fumigated/view (cited 2 Dec 2019).

17. Nicholls SG, Quach P, von Elm E, et al. The REporting of Studies Conducted Using Observational Routinely-Collected Health Data (RECORD) Statement: Methods for Arriving at Consensus and Developing Reporting Guidelines. PLoS One. 2015; 10(5): e0125620, doi: 10.1371/journal.pone.0125620, indexed in Pubmed: 25965407.

18. World Health Organisation. Poison Severity Score. https://www.who. int/ipcs/poisons/pss.pdf (Accessed 19 December 2019).

19. Agence Nationale de Sécurité Sanitaire de l'alimentation, de l'environnement et du travail ANSES. Expositions à des préparations contenant des phosphures dans le cadre d'une activité portuaire ou maritime, ou lors de l'ouverture d'un conteneur. Étude rétrospective des observations enregistrées par les Centres antipoison et de toxicovigilance français (1999-2017). ANSES Sept 2018. https:// www.anses.fr/fr/system/files/Toxicovigilance2018SA0290Ra.pdf (Accessed 5 December 2019).

20. World Health Organisation WHO. The French imputability method. https://www.who.int/medicines/areas/quality_safety/safety_efficacy/trainingcourses/2imputabilitefr.pdf (Accessed 19 May 2019).

21. Phosphine (FT 179). Généralités-Fiche toxicologique-INRS. http:// www.inrs.fr/publications/bdd/fichetox/fiche.html?refINRS=FICHETOX_179 (Accessed 5 December 2019).

22. Hoffman RS, Howland MA, Lewin MA, Nelson LS. Goldfrank's Toxicologic Emergencies, 10th edition. McGraw-Hill Education, Europe 2015: 1381-1383.

23. International Labour Organisation. ICSC 0694 - PHOSPHINE . https:// www.ilo.org/dyn/icsc/showcard.display?p_version=2\&p_card_ id=0694 (Accessed 19 March 2019).

24. The Emergency Response Safety and Health Database: Lung Damaging Agent: PHOSPHINE-NIOSH. https://www.cdc.gov/niosh/ershdb/ emergencyresponsecard_29750035.html (Accessed 19 March 2019).

25. Occupational Cancer - Carcinogen List - NIOSH Safety and Health Topic . https://www.cdc.gov/niosh/topics/cancer/npotocca.html (Accessed 19 March 2019).

26. Baur X, Budnik LT, Zhao Z, et al. Health risks in international container and bulk cargo transport due to volatile toxic compounds. J Occup Med Toxicol. 2015; 10: 19, doi: 10.1186/s12995-015-0059-4, indexed in Pubmed: 26075009.

27. Lucas D, Loddé B, Jegaden D, et al. Phosphine exposure in maritime foodstuff transportation: a recent case along logistic chain. Proceedings of the 2nd International DiMoPEx conference. Journal of Health and Pollution. 2018; 8(17): S1-S77. 
28. Pedersen R, Jepsen J, Ádám B. Regulation and practice of workers' protection from chemical exposures during container handling. J Occupat Med Toxicol. 2014; 9(1), doi: 10.1186/s12995-014-0033-6.

29. Rapport 10/2014 Omvang, aard en ernst van incidenten met blootstelling van werknemers aan schadelijke gassen uit (gegaste) containers. NVIC. Umcutrecht.nl. 2014. https://www.umcutrecht. $\mathrm{nl}$ /getmedia/1b18d8b2-ed36-4238-a472-34fa113179a1/ Incidenten-met-blootstelling-aan-containergassen.pdf.aspx?ext=. pdf (Accessed 19 March 2019)

30. Preisser AM, Budnik LT, Baur X. Health effects due to fumigated freight containers and goods: how to detect, how to act.
Int Marit Health. 2012; 63(3): 133-139, indexed in Pubmed: 23129094.

31. Preisser AM, Budnik LT, Hampel E, et al. Surprises perilous: toxic health hazards for employees unloading fumigated shipping containers. Sci Total Environ. 2011; 409(17): 3106-3113, doi: 10.1016/j.scitotenv.2011.04.053, indexed in Pubmed: 21636109.

32. Verschoor A, Leeuwen Hv, Verschoor L. Health problems in handling gassed containers. Zentralblatt für Arbeitsmedizin, Arbeitsschutz und Ergonomie. 2014; 60(7): 246-247, doi: 10.1007/ bf03344291. 